\title{
Professionals' Preference for Migrant Craftsmen in Lagos State
}

\author{
${ }^{*}$ Adedeji Afolabi ${ }^{1}$ \\ ljeoma Emeghe ${ }^{2}$ \\ Opeyemi Oyeyipo ${ }^{3}$
}

\begin{abstract}
Rapheal Ojelabi 4
1Department of Building Technology, Covenant University, Ota, Nigeria

2Department of Estate Management, Covenant University, Ota, Nigeria

${ }^{3}$ Department of Quantity Surveying, Bells University of Technology, Ota, Nigeria

${ }^{4}$ Department of Building Technology, Covenant University, Ota, Nigeria

Email: *1 adedeji.afolabi@covenantuniversity.edu.ng (Corresponding Author); 2 ijeoma.emeghe@covenantuniversity.edu.ng

33yeyipoo@gmail.com; ${ }^{3}$ rapheal.ojelabi@covenantuniversity.edu.ng; 1,2,3,4 Assistant Lecturer
\end{abstract}

\section{Doi:10.5901/mjss.2016.v7n1p501}

\section{Abstract}

It is difficult to fathom the words 'skilled labour shortage' in a country of over 160 million, but the challenge of shortage of trained skilled construction labour is glaring in the industry. The purpose of the study was to examine Professionals' preference for Migrant Craftsmen in Lagos State. A survey research design through the administration of questionnaires was used for the study. A convenience sampling method was used for the study in a vibrant sample area Lekki, Lagos where there are high volumes of building construction activities. From the forty-five (45) construction sites visited in Lekki, Lagos only thirty (30) construction sites were responsive to the study representing a $67 \%$ response rate. The data were compiled and calculations performed using SPSS 21.0. The result showed that migrant craftsmen from major four (4) countries in West Africa namely Benin, Ghana, Niger and Togo, are preferred by construction professionals for crafts work on building construction sites. The factor influencing the choice of Migrant craftsmen is due to the shortage of skilled local Craftsmen in the construction industry. The major factors militating against the use of local craftsmen are that they cut corners in carrying out their craft, they rush their work and they are not keen on improving their trainings. The preference for Migrant craftsmen would result in an adequate supply of craftsmen in the industry and consequently unemployment for local craftsmen. It was recommended that local content Act should be enacted and enforced for construction companies in the Nigerian construction industry to ensure an adequate quota for local professionals and craftsmen on construction sites. Nigerian institutions aimed at providing trade skill improvement programs for local craftsmen should be revamped in order to obtain skills to evolve and survive in the competitive construction industry.

Keywords: Construction Industry, Craftsmen, Migrant, Preference, Professionals.

\section{Background of the Study}

The underlying socio-economic contributions of the Nigerian construction industry can be felt in every sphere. From fulfilling human livelihood needs to infrastructure, down to the nation's economy. The industry is strategic in every society, as the largest employer of labour which attracts large amounts of investment in order to provide necessary infrastructure to nations. Fagbenle, Lawal and Omuh (2012) asserted the high influx of workers in the sector. Aynur et al. (2008) estimated that in developing countries, construction labour accounted for the largest percentage of total project costs (i.e., as much as $40 \%$ of direct capital cost in large construction projects). Izam and Onundi (2000) explained that construction plants and equipment have become increasingly expensive, beyond the reach of most indigenous builders thereby influencing the increase of unskilled and semi-skilled labour of low wage rates. As labour is realized to be a major contributor to the success of any construction project (Hickson and Ellis, 2014).

In a country of over 160 million, one would have expected a surfeit of trained skilled workforce. But, skilled Nigerian craftsmen are scare (Lawal and Tunji-Olayeni, 2011; Odusami and Ene, 2011). Researchers have reported on the sharp implications for business and the economy (Ireland, 2007; McCausland, 2008).

Attah, Audu and Haruna (2013) noted that the informal sector including artisans contributes 60 percent of Nigeria's 
Gross Domestic Product (GDP), but has not received the required attention. The place of craftsmanship in the construction industry is central. A large percentage of quality on the construction project hinges on the skill of the craftsmen and artisans. On the increase now is the indescribable urge for the use of migrant craftsmen on construction projects by professionals. This urge is adding to the already defaced sector in one way or the other. The unfair competition between the local and migrant craftsmen is becoming alarming with projects deemed incomplete only until a migrant craftsman has done the crafts work in it. This subsector is moving to the edge of such complains that indigenous construction firms have about their foreign counterpart in the Nigerian construction industry. With the idea that migrant workers have come to take over their jobs, craftsmen wander about jobless or go into the 'okada' or 'Napep' transportation business. Oluwale, Jegede and Olamade (2013) revealed that over three quarter of commercial motorcyclists were formerly craftsmen. It is viable to point out that the migration into this sector is unable to solve the developmental issues confronting the nation.

The use of migrant workers in Nigeria is not a unique phenomenon but a global issue. The recent economic crisis resulted in the total population of the European Union rise by 3.7 million with migrant workers (15-60 years) making approximately half of the increase. International organization for Migration (2012) stated that the migrants in the European Union are on average younger than the national population resulting in an increased rate of unemployment reaching 9.6 percent in 2010. Abdul-Aziz (2001) reported an increase in use of migrant skilled workers from 40 percent in 1983 to 80 percent in 1992 in the Malaysian construction industry. The Nigerian scenario is not different. Table 1.1 shows a summary of non-Nigerian construction workers from 2010 - 2012. The table revealed that there has been a steady increase in the number of non-Nigerian construction workers at over $3 \%$ yearly. With this trend, the solving the issues of unemployment would relatively be a mirage. It is estimated that over 500,000 Chinese artisans currently work in various countries on the African continent, including Nigeria, with over 9 billion naira been lost annually to foreign artisans (IhuaMaduenyi, 2015).

Table 1.1. Non-Nigerians engaged in the Nigerian Construction industry

\begin{tabular}{lccc}
\hline & & Year & \\
& 2010 & 2011 & 2012 \\
Number of persons engaged (Male) & 147,633 & 150,719 & 157,664 \\
Number of persons engaged (Female) & 7,202 & 8,488 & 7,716 \\
Total & 154,835 & 159,207 & 165,380 \\
\hline
\end{tabular}

Source: National Bureau of Statistics (2015)

National Bureau of Statistics (2013) reported that every year additional $2.8 \%$ of the nation's population jostles for employment in the already saturated employment market. The national unemployment rate increased to 23.9 percent in 2011 with youth unemployment towering over 50 percent put at 20.3 million. However, Donald and Stephen (2010) noted how the informal sector has helped reduce the effect of unemployment on the nation. The same informal sector is becoming flooded with migrant workers, leaving more Nigerian youth unemployed which can be a major threat.

Taking note that the World Bank survey in 2011 revealed that half the numbers of youths that are delinquent and those that join insurgent groups are mainly driven by unemployment. A pointer is the alarming rebellious activities in certain parts of the nation. Oluwale et al. (2013) painted a precarious scenario for the Nigerian future due to the shortage of skilled labour. Hopefully, the nation has grown and would not return to the era of "Ghana must go" that heralded the illegal eviction of some migrant workers from the country. The unfair advantage on local craftsmen surges higher with professionals' preference for migrant craftsmen, in that they are better. With this, the shortage of local skilled labour and artisan would continue, inferiority would set in and this set of people may be deemed unfit for the crafts work.

According to Oseghale, Abiola-Falemu and Oseghale (2015) the poor image of the industry has unfavourably affected the popularity of craftsmanship as a career choice. Adeyemi (2000) identified job insecurity/employee turnover as a demotivator in the Nigerian construction industry which impedes productivity improvements. Craftsmen nowadays, do not even encourage their children to follow their parent's trade, they would rather force their children to search for white collar jobs that are not available. The study aims to examine Professionals' preference for migrant craftsmen in Lagos State. The purpose of this paper is not to deface or stop the use of migrant workers but to understand what motivates professionals' preference for migrant craftsmen rather than local craftsmen and thereby the local craftsmen can learn those positive marks. 


\section{Methodology}

The data for the study were obtained through a survey research design by administering questionnaires. A convenience sampling method was used for the study due to inability to get a comprehensive list of construction firms in the area under study. The study samples were drawn from the major commercial nerve centre in Nigeria notably Lagos State. The study area was selected because a large volume of construction activities in the country takes place in Lagos State. Specifically, Lekki, Lagos was selected as the sample area due to the high volume of private mass housing schemes by private developers in the area. The Professionals selected for the study were limited to Architect, Builders and Quantity Surveyors actively involved in managing of building construction sites. From the forty-five (45) construction sites visited in Lekki, Lagos only thirty (30) construction sites were responsive to the study representing a $67 \%$ response rate. The study highlighted twelve (12) major crafts and nine (9) nationalities from the West African region with close boundaries to Nigeria. The data were compiled and calculations performed using SPSS 21.0. The result was analyzed using frequencies, percentages for the background information and the Mean score was used for ranking the objectives.

\section{Results and Discussion}

Data collected from the questionnaire responses were analysed and presented here in tables. The presentation is in order of appearance in the questionnaires.

\subsection{Background Information}

In order to sufficiently examine Professionals' preference for migrant craftsmen in Lagos State, the respondents were asked to provide background information to show suitability in completing the questionnaire. Table 4.1 shows the summary of background information of the respondent.

Table 3.1. Background Information

\begin{tabular}{lccc}
\hline Background Information & Frequency & Percent (\%) & Cumulative Percent \\
\hline Profession of Respondents & 7 & 23.3 & 23.3 \\
Architect & 18 & 60.0 & 83.3 \\
Builder & 5 & 16.7 & 100.0 \\
Quantity Surveyor & & & \\
Academic Qualification & 1 & 3.3 & 3.3 \\
PGD & 8 & 26.7 & 30.0 \\
BSc/B.Tech & 14 & 46.7 & 76.7 \\
MSc & 7 & 23.3 & 100.0 \\
PhD & & & \\
Professional Qualification & 7 & 23.3 & 23.3 \\
NIA & 18 & 60.0 & 83.3 \\
NIOB & 5 & 16.7 & 100.0 \\
NIQS & & & \\
Working Experience in construction industry & 3 & 10.0 & 10.0 \\
1-5 & 13 & 43.3 & 53.3 \\
6-10 & 8 & 26.7 & 80.0 \\
11-15 & 6 & 20.0 & 100.0 \\
Above 26 & & & \\
\hline
\end{tabular}

From the table, it showed that Builders had the highest participation in the study with $18(60.0 \%)$ respondents, while Architects and Quantity Surveyors had 7 (23.3\%) and 5 (16.7\%) respondents respectively. The academic qualification of the selected Project Managers showed that 14 (46.7\%) respondents had a highest academic qualification, this is followed by Project Managers who had highest academic qualification of $8(26.7 \%)$ respondents, this is closely followed by Project Managers who had PhD degrees with 7 (23.3\%) and only 1 (3.3\%) had PGD. The Professional qualifications of the respondents showed that $18(60.0 \%)$ of the respondents were affiliated with the Nigerian Institute of Building, while 7 (23.3\%) of the respondents were members of the Nigerian Institute of Architecture and 5 (16.7\%) were members of Nigerian Institute of Quantity Surveyors. The background information table revealed that most of the respondents had 610 years' experience, this was indicated by $13(43.3 \%)$ of the respondents while $8(26.7 \%)$ of the respondents had $11-15$ 
years' experience, $6(20.0 \%)$ of the respondents had above 26 years' experience and $3(10.0 \%)$ of the respondents indicated they had 1-5 years' experience.

\subsection{Migrant Craftsmen in use on Construction Sites}

This section identified twelve (12) construction trades in the Nigerian construction industry and examined the use of migrant workers in various aspects of the trade on construction sites.

Table 3.2. Migrant Craftsmen in use on construction sites

\begin{tabular}{|c|c|c|c|c|}
\hline Trade & Nationality & Frequency & Percent (\%) & Cumulative Percent \\
\hline \multirow[t]{4}{*}{ Carpentry } & Ghanaian & 11 & 68.75 & 68.75 \\
\hline & Togolese & 3 & 18.75 & 87.50 \\
\hline & Beninese & 1 & 6.25 & 93.75 \\
\hline & Nigerien & 1 & 6.25 & 100.0 \\
\hline \multirow[t]{3}{*}{ Tiling works } & Togolese & 15 & 50.0 & 50.0 \\
\hline & Beninese & 12 & 40.0 & 90.0 \\
\hline & Ghanaian & 3 & 10.0 & 100.0 \\
\hline \multirow[t]{4}{*}{ Plastering/Screeding works } & Togolese & 10 & 45.5 & 45.5 \\
\hline & Beninese & 6 & 26.1 & 71.6 \\
\hline & Ghanaian & 4 & 17.4 & 89.0 \\
\hline & Nigerien & 3 & 13.0 & 100.0 \\
\hline \multirow[t]{4}{*}{ Block laying works } & Nigerien & 14 & 53.8 & 53.8 \\
\hline & Ghanaian & 8 & 30.8 & 84.6 \\
\hline & Beninese & 3 & 11.5 & 96.1 \\
\hline & Togolese & 1 & 3.9 & 100.0 \\
\hline \multirow[t]{2}{*}{ Painting } & Ghanaian & 8 & 72.7 & 72.7 \\
\hline & Beninese & 3 & 27.3 & 100.0 \\
\hline \multirow[t]{2}{*}{ Welding works } & Ghanaian & 15 & 78.9 & 78.9 \\
\hline & Nigerien & 4 & 21.1 & 100.0 \\
\hline \multirow[t]{2}{*}{ Laying interlocking blocks } & Beninese & 12 & 75.0 & 75.0 \\
\hline & Ghanaian & 4 & 25.0 & 100.0 \\
\hline \multirow[t]{2}{*}{ Electrical works } & Ghanaian & 8 & 80.0 & 80.0 \\
\hline & Togolese & 2 & 20.0 & 100.0 \\
\hline \multirow[t]{2}{*}{ Concreting works } & Nigerien & 15 & 78.9 & 78.9 \\
\hline & Beninese & 4 & 21.1 & 100.0 \\
\hline \multirow[t]{3}{*}{ Roofers } & Beninese & 6 & 50.0 & 50.0 \\
\hline & Nigerien & 3 & 25.0 & 75.0 \\
\hline & Ghanaian & 3 & 25.0 & 100.0 \\
\hline
\end{tabular}

Table 3.2 showed the migrant craftsmen in use on construction sites in Lagos State. The table, Carpentry had four (4) prominent nationality identified in the study with Ghanaians leading with $11(68.75 \%)$ of the respondents indicating their use for Carpentry works. Respondents indicated three (3) nationalities in use for Tiling works with Togolese leading the pack with $15(50 \%)$, while in Plastering/Screeding works indicated four (4) nationalities with Togolese ranking $1^{\text {st }}$ in their use for Plastering/Screeding works. Project Managers indicated that in block laying works on construction sites Nigerien were mostly used with 14 (53.8\%). Other trades include Painting which led with Ghanaian; 8 (72.7\%), Welding led with Ghanaians; 15 (78.9), Laying interlocking blocks led with Beninese; 12 (75\%), Electrical works led with Ghanaians; 8 (80\%), Concreting works led with Nigerien; 15 (78.9\%) and Roofers led with Beninese; 6 (50\%). The result showed that migrant craftsmen from major four (4) countries in West Africa namely Benin, Ghana, Niger and Togo, are preferred by construction professionals for crafts work such as Tiling, Welding, Carpentry, Plastering/Screeding, Laying of interlocking blocks and Roofing on building construction sites. Ihua-Maduenyi (2015) reported that a large percentage of migrants come through the South-West, Ogun State while others from Cameroun migrate through the South-South borders of the country. Oluwale et al. (2013) and Oseghale et al. (2015) reiterated the shortage of craftsmen among bricklayers, carpenters, plumbers and painters. Leading to a surge to fill such vacant craftsmanship spaces on the construction sites. Bamisile (2004) predicted that in the next ten (10) years due to the low patronage of vocational and technical institutions it would be difficult to source for adequately skilled craftsmen. It is evident that the training and retraining programmes in neighboring countries through vocational and technical institutions have largely recorded successes that ensures skilled 
labour that are exported to Nigeria and other countries. This supported by Oluwale et al. (2013) noting that demand for vocational education seems to be on the low in Nigeria while the demand is on the high in other countries thereby leading to growth and diversification in those countries.

\subsection{Factors influencing the choice of Migrant Craftsmen}

Table 3.3 showed the factors influencing the choice of Migrant craftsmen in the construction industry. The table revealed that Shortage of Skilled local Craftsmen had mean score (MS) of 4.60, while Need for increased quality had MS $=4.30$, Dexterity of craftsmanship had MS $=4.03$ and Increasing client satisfaction had 3.93 mean score, Ability to obey instructions ( $M S=3.67$ ), Discipline ( $M S=3.63$ ), Ability to listen to correction ( $M S=3.57$ ), Need for less supervision (MS = 3.50), Punctuality to work site ( $M S=3.47)$, Speed of carrying out crafts work ( $M S=3.47$ ), Flexibility at work $(M S=3.43)$, Low price quotation for building works ( $M S=3.23$ ), Adequate mobilization to site ( $M S=3.23$ ), Large pool of migrant workers in the industry (MS = 3.20), Absence of disputes on works $(M S=3.13)$, Cleaner work site after completion ( $M S=$ 2.93), Quick understanding of works to be done ( $M S=2.83$ ), Complexity of building works ( $M S=2.73)$, Adequate communication ( $M S=2.33$ ), Availability of tools to carry out the job ( $M S=2.27$ ), Policies of construction firms/contractor $(M S=1.90)$ and Quick response to design changes (MS = 1.87).

Table 3.3. Factors influencing the choice of Migrant Craftsmen

\begin{tabular}{lcc}
\hline Factors & Mean Score & Ranking \\
\hline Shortage of Skilled local Craftsmen & 4.60 & 1 \\
Need for increased quality & 4.30 & 2 \\
Dexterity of craftsmanship & 4.03 & 3 \\
Increasing client satisfaction & 3.93 & 4 \\
Ability to obey instructions & 3.67 & 5 \\
Discipline & 3.63 & 6 \\
Ability to listen to correction & 3.57 & 7 \\
Need for less supervision & 3.50 & 8 \\
Punctuality to work site & 3.47 & 9 \\
Speed of carrying out crafts work & 3.47 & 9 \\
Flexibility at work & 3.43 & 11 \\
Low price quotation for building works & 3.23 & 12 \\
Adequate mobilization to site & 3.23 & 12 \\
Large pool of migrant workers in the industry & 3.20 & 14 \\
Absence of disputes on works & 3.13 & 15 \\
Cleaner work site after completion & 2.93 & 16 \\
Quick understanding of works to be done & 2.83 & 17 \\
Complexity of building works & 2.73 & 18 \\
Adequate communication & 2.33 & 19 \\
Availability of tools to carry out the job & 2.27 & 20 \\
Policies of construction firms/contractor & 1.90 & 21 \\
Quick response to design changes & 1.87 & 22 \\
\hline
\end{tabular}

Table 3.3 revealed that Shortage of Skilled local Craftsmen ranked $1^{\text {st }}$ and is a very significant factor increasing the use of Migrant Craftsmen. Quick response to design changes as a factor ranked least on the table. The increasing housing needs and the developing economy have contributed to the rise in construction projects. The prerequisite to the rising construction industry is the need for skilled craftsmen. But, Odusami and Ene (2011) noted the Nigerian construction industry is filled with unskilled, inefficient and dissatisfied workers which has reduced the stock of competent skilled construction workers. Bamisile (2004) observed that there are no more serious formal vocational centres in Nigeria. In findings by Oseghale et al. (2015) about 80 percent of construction managers reported shortage of Bricklayers, Carpenters, Painters and Plumbers. Lawal and Tunji-Olayeni (2011) reported on the under-utilization of local craftsmen thereby leading to change of employment. Therefore, due to this shortage of construction craftsmen supply, the country would continually experience the influx of migrant and foreign artisans to satisfy the construction crafts' demand. 


\subsection{Factors militating against the use of Local Craftsmen}

The study set out to examine professionals' preference for migrant craftsmen in Lagos State. Table 3.4 showed the factors militating against the use of local Craftsmen. Table 3.4 indicated that Cutting corners had a mean score (MS) of 4.13 thereby ranking $1^{\text {st }}$ on the table. Rush work by the local craftsmen ranked $2^{\text {nd }}$ with a mean score (MS) of 4.10. Inability to improve training ( $M S=3.80)$, Inability to listen to corrections $(M S=3.77)$, Lack of patience on work (MS = 3.77), Lateness to work ( $M S=3.73$ ), Excessive complain and excuses ( $M S=3.67)$, Untidy tools and work area (MS = 3.50), Alcoholism and drug abuse (MS = 3.50), Charging exorbitant prices ( $M S=3.43)$, Pilfering of materials $(M S=3.40)$, Lack of integrity (MS $=3.40$ ), Poor obedience to instructions (MS $=3.37$ ), Lack of tools (MS $=3.00$ ) and Slowness at carrying out their duties (MS $=2.77)$.

Table 3.4. Factors militating against the use of Local Craftsmen

\begin{tabular}{lcc}
\hline Factors & Mean score & Ranking \\
\hline Cutting corners & 4.13 & 1 \\
Rush work & 4.10 & 2 \\
Inability to improve training & 3.80 & 3 \\
Inability to listen to corrections & 3.77 & 4 \\
Lack of patience on work & 3.77 & 4 \\
Lateness to work & 3.73 & 6 \\
Excessive complain and excuses & 3.67 & 7 \\
Untidy tools and work area & 3.50 & 8 \\
Alcoholism and drug abuse & 3.50 & 8 \\
Charging exorbitant prices & 3.43 & 10 \\
Pilfering of materials & 3.40 & 11 \\
Lack of integrity & 3.40 & 11 \\
Poor obedience to instructions & 3.37 & 13 \\
Lack of tools & 3.00 & 14 \\
Slowness at carrying out their duties & 2.77 & 15 \\
\hline
\end{tabular}

The result of the table revealed that most of the respondents agree that local craftsmen are prone to cutting corners on construction sites. Oseghale et al. (2015) reported about the unattractive image of the subsector causing craftsmen to exit the sector to other sectors. It is worthy to note that the skills possessed by these craftsmen have no technical value to these other sectors (Lawal and Tunji-Olayeni, 2011; Oluwale et al., 2013). Oseghale et al. (2005) identified factors such as low wages and no career path amongst others for the shortage in skilled craftsmen. This is supported by Oluwale et al. (2013), in that over $35 \%$ of tradesmen left the profession to the transportation sector due to low wages. Lawal and TunjiOlayeni (2011) explained that craftsmen's desires to meet necessary needs are mainly concerned about increasing how much is earned. This can be related to reasons some local craftsmen that still remain on the job are willing to cut corners due to the low wage regime in order to make ends meet.

\subsection{Effects of Using Migrant Craftsmen}

The continuous use of migrant craftsmen on construction sites in Lagos State was assessed as shown in Table 3.5. The table 3.5 showed the effects of using Migrant Craftsmen in the Construction Industry.

Table 3.5. Effects of using Migrant Craftsmen in the Construction Industry

\begin{tabular}{lcc}
\hline Effects & Mean score & Ranking \\
\hline Adequate supply of workers for crafts work & 4.50 & 1 \\
Unemployment of local craftsmen & 4.27 & 2 \\
Increase in quality of crafts work & 4.13 & 3 \\
Increased customer satisfaction & 4.03 & 4 \\
Quick delivery of crafts work & 4.03 & 4 \\
Increased profit for contractor/construction firm & 3.97 & 6 \\
Lack of cooperation between local and migrant craftsmen & 3.87 & 7 \\
Cost saving on crafts work & 3.80 & 8
\end{tabular}




\begin{tabular}{lcc} 
Introduction of new techniques to craftsmanship & 3.77 & 9 \\
Cleanliness of work site & 3.47 & 10 \\
Effective use of construction materials & 3.40 & 11 \\
Reduction in construction waste & 3.30 & 12 \\
Economic growth & 3.07 & 13 \\
Increase in number of housing output & 2.90 & 14 \\
Increased dispute between management and craftsmen & 2.37 & 15 \\
Improved communication between management and craftsmen & 1.87 & 16 \\
\hline
\end{tabular}

The table revealed that adequate supply of workers for crafts work had a mean score (MS) of 4.50, Unemployment of local craftsmen had 4.27, Increase in quality of crafts works had 4.13 while increased customer satisfaction and quick delivery of crafts work both had a mean score (MS) of 4.03. Increased profit for contractor/construction firm (MS = 3.97), Lack of cooperation between local and migrant craftsmen ( $M S=3.87$ ), Cost saving on crafts work ( $M S=3.80$ ), Introduction of new techniques to craftsmanship (MS = 3.77), Cleanliness of work site (MS = 3.47), Effective use of construction materials ( $M S=3.40$ ), Reduction in construction waste $(M S=3.30)$, Economic growth $(M S=3.07)$, Increase in number of housing output (MS = 2.90), Increased dispute between management and craftsmen (MS = 2.37) and Increased communication between management and craftsmen (MS = 1.87). Table 3.5 revealed that adequate supply of workers for crafts work ranked $1^{\text {st }}$ making it the most critical effect of using migrant workers in the construction industry. Followed by Unemployment of local craftsmen which ranked $2^{\text {nd }}$ and Increase in the quality of crafts work which ranked $3^{\text {rd }}$. Improved communication between management and craftsmen ranked least. Akindoyeni (2005) reported that demand for construction craftsmen is far above the supply. Whereby, Odusami and Ene (2011) stated that there have been large incidences of construction firms poaching trained skilled personnel from other firms. The demand created by increasing population and housing needs in the country. Odusami and Ene (2011) suggested an equilibrium between the demand and supply of construction crafts demand through a developmental programme. Ogbeifun (2011) explained that due to the decline in the supply of skilled artisans there has been an increase in the use of subcontractors to balance the equilibrium. With immigrant skilled workers forming a significant amount of the subcontractors' team to execute the craft (Abdul-Aziz, 2001; Prayag, 2005). Therefore, it is rest assured that there would be adequate supply to fill the demands of contractors to boost the stock of housing needs.

\section{Conclusion and Recommendation}

From the result of the study it can be concluded that migrant workers in the West African region are used to carry out some selected crafts work on building construction sites. Shortage of skilled local craftsmen is a major factor influencing the use of migrant craftsmen on building construction sites. Factor militating against the use of local craftsmen indicated that local craftsmen are used to cutting corners while carrying out their duties on construction sites. Other complaints indicated that local craftsmen rush their works and are not keen on improving their training. The effects of using migrant craftsmen in the construction industry revealed that there would be adequate supply of workers for crafts work and consequently creating unemployment for local craftsmen. It was recommended that there is a need to enact and enforce a local content Act in the Nigerian construction industry that ensures an adequate quota for local professionals and craftsmen on construction sites in order to protect the interest of the Nigerian citizenry in the construction industry. The need to rid the nation of corrupt practices that has submerged into the subsector should be of utmost concern. Local craftsmen should be sensitized through their local bodies inform of trainings and seminars on the need to show integrity at work and avoid cutting corners while carrying out their duties. Local craftsmen should be informed on the damage caused by cutting corners on the trade and the nation as a whole. The necessity for local craftsmen to improve their trainings cannot be over emphasized. Nigerian institutions aimed at trade skill improvement of local craftsmen should be revamped so as to encourage the continuous supply of local craftsmen in the construction industry. Construction firms and Professional bodies should also be involved in apprenticeship programmes aimed at training local craftsmen on skills required to evolve and survive in the competitive construction industry.

\section{References}

Abdul- Aziz, A.R. (2001). Construction in the eye of the workforce. In The Construction Industry in the Twenty-First Century: Its Image, Employment Prospects and Skills Requirements. (Ed) International Labour Office, 2001, Geneva, 1- 67

Adeyemi, A.Y. (2000). Management Prescriptions for Productivity Improvement on Mass Housing Projects. In: Akinbamijo, O.B., Fawehinmi, A.S., Ogunsemi, D.R. and Olutuah, A. (Eds.) Effective Housing in the 21st Century Nigeria, The Environmental 
Forum, Federal University of Technology, Akure, Nigeria, 63-74.

Akindoyeni, A. (2005). Nigerian Building Craftsmen; which way forward? Text of paper presented at the NIOB craftsmen's summit at Yaba College of Technology, Lagos. 7th July, 2005.

Attah A. P., Audu, J. S. \& Haruna, P. O. (2013). Strategy for Reducing Unemployment in Nigeria: The Role of Informal Sector. International Journal of Capacity Building in Education and Management (IJCBEM), 2 (1), 32 - 44.

Aynur, K., Ekrem, M. \& Serdar, U. (2008). Effect of basic motivational factors on construction workforce productivity in turkey. Journal of Civil Engineering and Management, 14 (2)

Bamisile, A. (2004). Building Production Management. Foresight Press Limited: Lagos, Nigeria

Donald, S. P. \& Stephen T. B. (2010). The informal sector in Sub-Saharan Africa: out of the shadows to foster sustainable employment and equity? International Business and Economic Research Journal, 9 (5)

Fagbenle, O.I., Lawal, P.O. \& Omuh, I.O. (2012). The Influence of Training on Bricklayers' Productivity in Nigeria. International Journal of Management, Sciences and Business Research, 1(7), 1-13.

Hickson, B. G. \& Ellis, L. A. (2014). Factors affecting Construction Labour Productivity in Trinidad and Tobago. The Journal of the Association of Professional Engineers of Trinidad and Tobago, 42 (1), 4-11.

Ihua-Maduenyi, M. (2015, February 16). Foreign artisans take over Nigeria's construction industry. Punch online Newspaper retrieved from http://www.punchng.com/special-feature/foreign-artisans-take-over-nigerias-construction-industryl

International Organization for Migration, IOM (2012). Migration, Employment and Labour market integration policies in the European Union - 2010. International Organization for Migration, Brussels, Belgium.

Ireland, B. (2007). Wanted: Skilled Labour. Skilled Labour Shortage in America. A Robust Economy Strains the ranks of a Qualified Workforce. USA. Penton Media Inc. Retrieved from: http:/lecmweb/mag/electric_wanted_skilled_labor/index.html

Izam, Y. D. \& Onundi, L. O. (2000). Man-hour loses on construction sites in a semi-arid zone. Journal of Environmental Revolution, 3 (1), $192-199$

Lawal, P. O. \& Tunji-Olayeni, P. F. (2011). Comparative Study of Work Output and Wages of Construction Craftsmen in the Nigerian Public Sector. Mediterranean Journal of Social Sciences, 2 (3), 139 - 145

McCausland, C. (2008). Labour Shortages Solutions. Combating the Lack of Skilled Craftsmen. The Builder News Magazine. USA. Retrieved July 20, 2014 from http://www.buildernewsmag.com/viewnews.pl?id

National Bureau of Statistics, NBS (2013). The Nigerian statistical fact sheets on Economic and Social Development, FOS, Nigeria.

National Bureau of Statistics, (NBS) (2015). Nigerian Construction summary report 2010 - 2012, Central Business District, Abuja

Odusami, K. T. \& Ene, G. U. (2011). Tackling the shortage of construction skills in Nigeria. A paper presented at a2-day national seminar organized by the Nigerian Institute of Quantity Surveyors, vision 20-2020: strategic industry development within National Development Goals in Abuja,

Ogbeifun, E. (2011). Training artisans on-site. Australasian Journal of Construction Economics and Building, 11 (3), 82-91

Oluwale, B. A., Jegede, O. O. \& Olamade, O. O. (2013). Technical and vocational skills depletion in Nigeria and the need for policy intervention. International Journal of Vocational and Technical Education, 5 (6), 100 -109

Oseghale, B. O., Abiola-Falemu, J. O. \& Oseghale, G. E. (2015). An Evaluation of Skilled labour shortage in selected construction firms in Edo state, Nigeria. American Journal of Engineering Research (AJER), 4 (1), 156 - 167

Prayang, A. (2005). A protective net. The Hindu Business Line, Available at http://www.thehindubusinessline.com/life/2005/05/13113/ stories/2005051300160400.htm 15-07-09 Retreived July 20, 2014 